\title{
Physical characteristics of baru tree fruit aimed at kernel extraction
}

\section{Características físicas do fruto do baruzeiro visando a extração da amêndoa}

\author{
Bruno de Andrade Martins ${ }^{1 *}$; Antonio Carlos de Oliveira Ferraz ${ }^{2}$; Flávio Luís Schmidt ${ }^{3}$
}

\begin{abstract}
The baru tree fruit has a sustainable economical potential. However, the shelling process to release the whole kernel, the most valued part of the fruit, is still performed in a rather inefficient way. The objective of this investigation was to determine the physical-mechanical properties of the fruit to understand its behavior during shelling. Fruit and nut were characterized by unit mass, dimensions, volume and bulk, and real densities. Compression tests up to endocarp disruption were performed to determine maximum force, corresponding deformation, and deformation energy. X-ray tomography was used to identify potential nut internal dimension changes, affected by the treatments. Whole fruits and nuts showed average unit mass values of $28.20 \pm 0.99 \mathrm{~g}$ and $16.52 \pm 1.67 \mathrm{~g}$, respectively. Their average dimensions, such as length, width, and thickness were $52.40 \pm 4.48 \mathrm{~mm}, 38.31 \pm 4.05 \mathrm{~mm}$, and $28.64 \pm 3.67 \mathrm{~mm}$, and $50.78 \pm 5.57 \mathrm{~mm}, 34.65 \pm 5.14 \mathrm{~mm}$, and $21.36 \pm 2.86 \mathrm{~mm}$, respectively. Average bulk and real densities values were $519.33 \pm 49.63 \mathrm{~kg} / \mathrm{m}^{3}$ and $918.87 \pm 77.77 \mathrm{~kg} / \mathrm{m}^{3}$, and $517.14 \pm 41.88 \mathrm{~kg} / \mathrm{m}^{3}$ and $1072.00 \pm 187.01 \mathrm{~kg} / \mathrm{m}^{3}$, respectively. Considering all treatments, the average rupture force ranged between 7926.7 and $9284.4 \mathrm{~N}$, with corresponding widthwise specific deformation of $5.1 \%$ and $6.6 \%$, to release $100 \%$ whole kernels of the tested nuts. Up to maximum force, deformation energy values ranged between 6.55 and 9.26J. There was no evidence of treatments' effect on the internal dimension. Based on its mechanical behavior, showing that it is possible to open the endocarp and release the whole kernel, it was concluded that the baru nut has mechanized shelling potential.
\end{abstract}

Key words: Dipteryx alata Vog. Mechanical properties. Disruption. X-rays tomography.

\section{Resumo}

O fruto do baruzeiro apresenta potencial econômico sustentável, mas o processo de decorticação com liberação de amêndoa inteira, a parte mais valiosa, é ainda realizada de forma um tanto ineficiente. $\mathrm{O}$ objetivo nesta investigação foi determinar suas propriedades físico-mecânicas visando compreensão do seu comportamento durante a decorticação. Fruto e castanha foram caracterizados pela massa, volume e dimensões unitários e massas específicas aparente e real. Ensaios de compressão até a ruptura do endocarpo foram realizados para determinar a força máxima, deformações correspondentes e energia de deformação. Utilizou-se da tomografia de raio-X para investigar potenciais modificações, causadas pelos tratamentos, nas dimensões internas. Fruto e castanha apresentaram massa unitária média de 28,20 $\pm 0,99$ e $16,52 \pm 1,67 \mathrm{~g}$, respectivamente. O comprimento, a largura e a espessura médias foram $52,40 \pm$ $4,48,38,31 \pm 4,05$ e $28,64 \pm 3,67 \mathrm{~mm}$, e $50,78 \pm 5,57,34,65 \pm 5,14$ e $21,36 \pm 2,86 \mathrm{~mm}$, respectivamente. Os valores médios das massas específicas aparente e real foram 519,33 $\pm 49,63$ e 918,87 $\pm 77,77 \mathrm{~kg} / \mathrm{m}^{3}$,

\footnotetext{
${ }^{1}$ Prof., Instituto Federal de Educação, Ciência e Tecnologia Goiano, IFGoiano, Campus Hidrolândia, GO, Brasil. E-mail: bruno. martins@ifgoiano.edu.br

2 Prof., Faculdade de Engenharia Agrícola, Universidade Estadual de Campinas, UNICAMP, Campinas, SP, Brasil. E-mail: acarlos. ferraz@gmail.com

${ }^{3}$ Prof., Departamento de Tecnologia de Alimentos, Faculdade de Engenharia de Alimentos, UNICAMP, Campinas, SP, Brasil. E-mail: schmidt@fea.unicamp.br

* Author for correspondence
} 
e $517,14 \pm 41,88$ e $1072,00 \pm 187,01 \mathrm{~kg} / \mathrm{m}^{3}$, respectivamente. Considerando todos os condicionamentos, a força média de ruptura do endocarpo variou entre 7926,7 e 9284,4 N, com deformação específica entre 5,1 e $6,6 \%$ da largura para a obtenção de $100 \%$ de amêndoas inteiras. Os valores médios de energia de deformação até a força máxima variaram entre 6,55 e 9,26 J. Não foi possível evidenciar os efeitos dos diversos condicionamentos nas dimensões internas. Devido ao seu comportamento mecânico evidenciar a possibilidade de abertura do endocarpo com liberação de amêndoa inteira, concluiu-se que existe potencial para a decorticação mecanizada da castanha de baru.

Palavras-chave: Dipteryx alata Vog. Baru. Propriedades mecânicas. Ruptura. Tomografia computadorizada.

\section{Introduction}

The dicotyledonous baru tree (Dipteryx alata Vog.) shows a promising economic exploitation due to its multiple uses, for food, fodder, timber, medicine, honey, and ornamental industries. It has the potential to be applied to projects that reconcile natural resources preservation with economic profitability, as it allows extra income for local people in the dry season. From the socioeconomic development point of view, technological research and productivity standards improvements are fundamental to reducing human pressure on the remaining area. The most valuable part of the baru is the kernel.

In nature the fruit has an average composition of $41.9 \%$ pulp (epicarp and mesocarp), 53.8\% woody endocarp, and $4.3 \%$ seed (kernel); and the nut (endocarp and kernel) has $92.01 \%$ endocarp and $8 \%$ kernel. Due to this composition, the residue of the baru tree's processing to obtain the kernel is about $95 \%$ of the processed fruit mass. Operations involved in kernel extraction are done by hand, using guillotine equipment with no operator safety. The fruit is cut with low efficiency and consequent low productivity, which is a negative side of processing, as well as involving high costs (CARRAZZA; ÁVILA, 2010).

It is necessary to broaden knowledge of the baru characteristics in order to develop effective, efficient, and safe equipment for kernel extraction. As a result, the aim of this study was to physically characterize the fruits (unit mass, length, width, thickness, volume and bulk, and real densities), to determine mechanical parameters (maximum force and its deformation, specific deformation and deformation energy at rupture), and to measure internal gaps between the kernel and the endocarp of the nuts subjected to several conditioning treatments. Conditioning is intended to change some of the fruit's mechanical properties to facilitate shelling. Neves (2012) used superheated water vapor and infrared radiation to change the mechanical properties of Brazil nuts as conditioning for shelling. Generally, the tissue to be broken needs to be stiffened, while still preserving its viscoelastic characteristic (BASTOS; FERRAZ, 2014).

\section{Materials and Methods}

In the 2005 harvest, ripe nuts differed from the fruit due to the absence of pulp after passing through the digestive tract of cattle, and then excreted. These were collected in the field by extractive communities in the Cerrado regions in the municipalities of Jussara and Pirenópolis, both in the state of Goiás, and placed in woven polypropylene bags containing approximately $30 \mathrm{~kg}$ each. The material was stored at the Laboratory of Fruit, Vegetables and Sugary Products of the Department of Food Technology, School of Food Engineering, FEA/Unicamp, under a controlled temperature of $24 \pm 1^{\circ} \mathrm{C}$ and humidity $63 \pm 2 \%$, until the experiment was performed. The fruits and nuts used in this work were taken randomly from this stock.

Bags containing baru fruits were weighed on a digital scale (Filizola MF, $\pm 20 \mathrm{~g}$ accuracy) to determine total mass of the sample from each 
municipality. Then the material was selected and grouped as natural fruit (CP) and nuts (SP), according to their morphological characteristics (CARRAZZA; ÁVILA, 2010). Fruit as well as nuts were mixed together.

The value of mass of each group was used to calculate the respective proportions $\left(\%_{\text {Group }}\right)$ through the ratio between the mass of the group and the total mass of each region, using equation (1).

$$
\%_{\text {Group }}=\left(\mathrm{M}_{\text {Group }} / \mathrm{M}_{\text {Region }}\right) * 100
$$

where,

$\mathrm{M}_{\text {Group }}$ - mass of each CP or SP group, kg;

$\mathrm{M}_{\text {Region }}$ - sample mass of fruits of a given region, $\mathrm{kg}$.

Then unit mass and volume, length, width, thickness, bulk, and real densities were measured. The methodology used was adapted from Alvarado and Aguilera (2001); that is, for volume determination, instead of water, millet seeds were used in order to not change the sample moisture content. Millet was used due to its small size and its established use in investigations with cereals (AACC, 2000). Fruit sampling was based on the Instituto Adolfo Lutz standards (2008). Average unit mass was determined by mass ratio of 50 units of fruit, carried out in triplicate, on a semi-analytical scale (Gehaka BG-4000, $\pm 0.01 \mathrm{~g}$ accuracy). The measurement of the real volume of fruit was made by the difference of the displaced volume in a test tube containing millet seeds, in triplicate. For measurements of length, width, and thickness, we used a caliper (Mitutoyo, $\pm 0.05 \mathrm{~mm}$ accuracy), considering the largest extent in each direction. Bulk density $\left(\rho_{\text {bulk }}\right)$ was obtained by the ratio between the mass of the sample measured using analytical scale (Mettler Toledo AB204) with a 1L test tube volume, avoiding crushing or compressing the material. The specific density ( $\rho$ ) of fruit was calculated by the ratio between the average unit mass and the volume values. Average values of measurements were analyzed using the coefficient of variation and means comparison (Tukey test, $\mathrm{p}<0.05$ ).

Preliminary tests showed that compression along the thickness, the natural nut resting position, provided endocarp rupture, but undesirably, the kernel was fragmented due to the high deformation value. Of the remaining options of longitudinal and cross-section compression, the latter was chosen by presenting a stable balance during compression between flat and parallel plates (Figure 1).

Figure 1. Baru fruit cross-section showing force application along the width, tomographic images reference planes, and gaps F1 and F2 between kernel and endocarp.

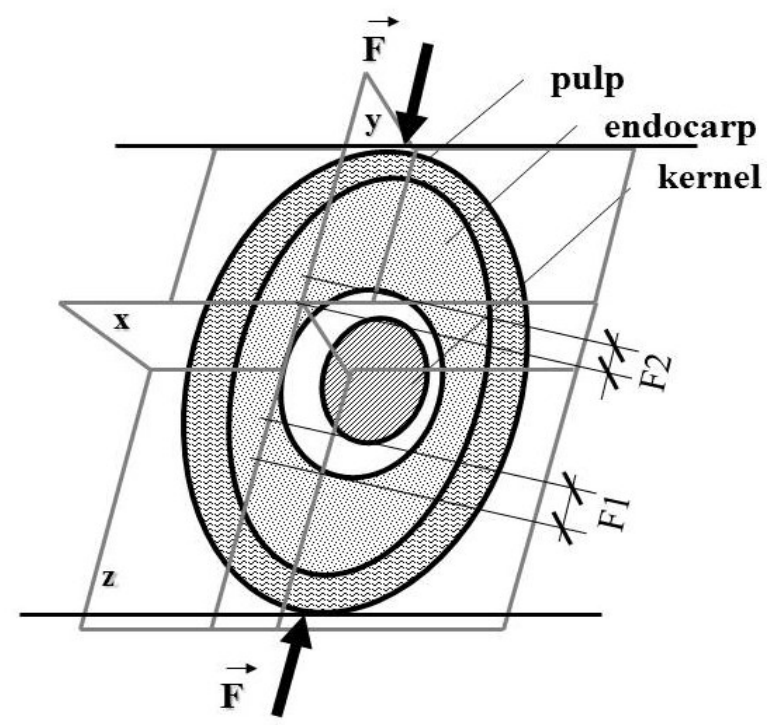

Compression tests were performed using a universal material testing machine of (EMIC, with a $300 \mathrm{kN}$ load cell and data acquisition assisted by software Tesc 3.05), at the Laboratory of Materials and Structures, School of Agricultural Engineering, FEAGRI/Unicamp. The value of the deformation rate was set at $1.0 \mathrm{~mm} / \mathrm{s}$, and kept constant during each test, regardless of the force build-up. This low value of strain rate mitigates the viscous expression of viscoelastic materials, and is commonly adopted in the mechanical testing of plant material (FERRAZ; HONÓRIO, 2008). To prevent specimen slippage during compression, two plates of carbon 
steel were built, one with a knurled surface fixed in the upper moving head, and the other with a "V"shaped recess set in the lower fixed base. Fruit was conditioned with the aim of producing favorable mechanical properties for endocarp disruption, and to obtain whole kernels. Conditioning treatments of baru specimens were: natural fruit $(\mathrm{CP})$; natural nuts (SP); nuts obtained from hydrated and pulped fruit $(\mathrm{H})$; and dry nuts $(\mathrm{S})$. Conditioning of $\mathrm{H}$ is an alternative to pulping, as hydration facilitates pulp removal. Hydration was carried out at $90^{\circ} \mathrm{C}$ for 30 minutes in water immersion, in a water mass ratio relative to fruit of 10:1. For this we used: pans, industrial stove (Dako, LPG), mercury thermometer ( $\pm 0.5^{\circ} \mathrm{C}$ accuracy), and pulping equipment (Sterling Speed-trol, with screen $1.6 \mathrm{~mm}$ opening, rotation $400 \mathrm{rpm}$ and $55 \mathrm{~mm}$ turning radius). Conditioning treatment for $\mathrm{S}$ is also an alternative to baru processing, with the possibility of roasting the kernel while still inside the endocarp. Drying the nuts was performed in an oven (Fanem $315 \mathrm{SE}$ ) at $150 \pm 3^{\circ} \mathrm{C}$ for 50 minutes. The moisture content of samples, on a dry basis (\%) of about 50 to $80 \mathrm{~g}$ endocarp for each conditioning, was determined in a forced air circulation oven (Fanem $315 \mathrm{SE}$ ) at 45 $\pm 3^{\circ} \mathrm{C}$, until they had a constant weight (AOAC, 2011). For compression tests batches of fruit and nuts with at least 25 specimens were used. The width of each specimen, previously numbered, was measured using a caliper (Mitutoyo, \pm 0.05 $\mathrm{mm}$ accuracy). For CP treatment, pulp, at opposite regions widthwise - that is, in the regions of contact with plates during compression-was removed to reduce the initial deformation of the pulp. For all tests, the specimens were carefully accommodated between plates, applying a minimum preload just sufficient to hold the specimen vertically along its width. Force-deformation curves were obtained from tests, allowing the determination of mechanical parameters such as maximum force $(\mathrm{N})$, and their corresponding deformation $(\mathrm{mm})$, specific deformation ( $\%$ or decimal), and deformation energy $(\mathrm{J})$, similar to other works for mechanical characterization of biological materials (BASTOS; FERRAZ, 2014; GHARIBZAHEDI et al., 2012a, 2012b; OGUNSINA; BAMGBOYE, 2013). Using the curves, the maximum force and its deformation $(\delta)$ were identified, allowing the calculation of the average specific strain $(\varepsilon)$, expressed by the ratio between deformation values $(\delta)$ and initial width $\left(\mathrm{L}_{0}\right)$, both measured in $\mathrm{mm}$. The deformation energy value (E) until rupture force was calculated by calculating the area under the force-deformation curve (GHARIBZAHEDI et al., 2012a). Average values obtained were presented with their respective coefficients of variation, and the results were subjected to analysis of variance (ANOVA) and means comparison (Tukey, $\mathrm{p} \leq 0.05$ ), with the assistance of Statistics for Windows, version 5.0.

This nondestructive technique determines variations in gap dimensions in the same specimen, between the kernel and the inner wall of endocarp, before and after each treatment. For this, microtomography with a camera (Hamamatsu 100/250 10 megapixels) and its associated imaging software were used. The acquisition of TIFF images, $17.41 \mu \mathrm{M}$ pixel, was performed in a period over 6-9 hours, with $100 \mathrm{kV}$ voltage, 100 $\mu \mathrm{A}$ current, aluminum and copper filter, distance between sample and radiation source of 260.407 $\mathrm{mm}$, distance between sample and camera of $346.708 \mathrm{~mm}$, and vertical position of $32.025 \mathrm{~mm}$, $42.470 \mathrm{~mm}$, and $42.660 \mathrm{~mm}$, respectively, for conditioning of $\mathrm{CP}$ (natural fruit), $\mathrm{H}$ (hydrated at $90^{\circ} \mathrm{C}$ for 30 minutes and pulped manually), and $\mathrm{S}$ (dried at $150^{\circ} \mathrm{C}$ for 50 minutes in an oven Fanem $315 \mathrm{SE}$ ), of a single specimen. Thus, DataViewer SkyScan 1.3.2 software was used to inspect threedimensional images, according to the schematic representation of visualization planes (Figure 1), positioning the $\mathrm{y}, \mathrm{x}$, and $\mathrm{z}$ axes along the length, width and thickness of the specimen. Using a crosssection image, located at about the widest portion of the kernel, the F gap ( $\mathrm{mm}$ ) was calculated by summing up the measured values F1 and F2 (Figure 1). There were six replications of this procedure, 
and the results of $\mathrm{F}$ were analyzed using ANOVA and means comparison (Tukey, $\mathrm{p}<0.05$ ). The images were obtained using Embrapa Agricultural Instrumentation in the São Carlos (SP) laboratory facilities.

\section{Results and Discussion}

Batches of baru tree fruits from the regions of Pirenópolis (GO) and Jussara (GO), weighing32.62 and $26.31 \mathrm{~kg}$, respectively, had $79.58 \%$ and $83.27 \%$ whole natural fruit (CP), respectively, and $20.42 \%$ and $16.73 \%$ of nuts (SP), respectively. Since specimens that have fallen from the tree are collected from the ground, it is expected that a mixture of whole fruits and nuts will be obtained. Since they have different properties, a separation stage is needed prior to the shelling process. Mean values obtained for the unit mass of CP and SP baru were $28.20 \pm 0.99 \mathrm{~g}$ and $16.52 \pm 1.67 \mathrm{~g}$, respectively, lower than values found by Corrêa et al., (2000), and 29.16 to $35.43 \mathrm{~g}$ for $\mathrm{CP}$ fruits from different regions of Goiás. The average dimension values of fruit and nuts (Table 1) indicate that fruit dimensions follow the oblong shape of the kernel. However the largest formation of pulp occurs along the thickest part.. Values found by Corrêa et al., (2000) for length, thickness, and width were 51.22 to $56.37 \mathrm{~mm}, 38.04$ to $42.25 \mathrm{~mm}$, and 29.74 to $30.96 \mathrm{~mm}$, respectively, similar to those found in this work for natural fruit.

Table 1. Mean and standard deviation values of length, width, and thickness for natural fruit and nuts.

\begin{tabular}{lccc}
\hline & Length $(\mathrm{mm})$ & width $(\mathrm{mm})$ & thickness $(\mathrm{mm})$ \\
\hline fruits & $52.68 \pm 4.9$ & $38.44 \pm 4.3$ & $28.51 \pm 4.0$ \\
nuts & $51.34 \pm 6.0$ & $35.31 \pm 5.0$ & $22.15 \pm 3.9$ \\
\hline
\end{tabular}

According to the histograms of frequency (Figures 2 and 3), a $26 \mathrm{~mm}$ sieve opening, suitably positioned in classification equipment, would be sufficient to separate CP and SP specimens, as $81 \%$ of CP specimens would be retained, and approximately $97 \%$ of SP specimens would pass through the space. This processing would facilitate subsequent pulping or shelling improvement.
Mean bulk density values were $519.33 \pm 49.63$ $\mathrm{kg} / \mathrm{m}^{3}$, and $517.14 \pm 41.88 \mathrm{~kg} / \mathrm{m}^{3}$ for CP and SP fruits, respectively, which is important for estimating silo volume for bulk storage.

$\mathrm{CP}$ and SP specimens showed average unit volumes of $41.25 \pm 5.61$ and $20.64 \pm 11.54 \mathrm{~mL}$, respectively, indicating significant pulp contribution in baru volume. For the same reason, the whole fruit is less dense than the nut, with average values for real density of $918.87 \pm 77.77$ and $1072.00 \pm 187.01$ $\mathrm{kg} / \mathrm{m}^{3}$, respectively. This may allow separation by density. 
Figure 2. Mean thickness (mm) cumulative percentage frequency histograms for natural baru (CP).

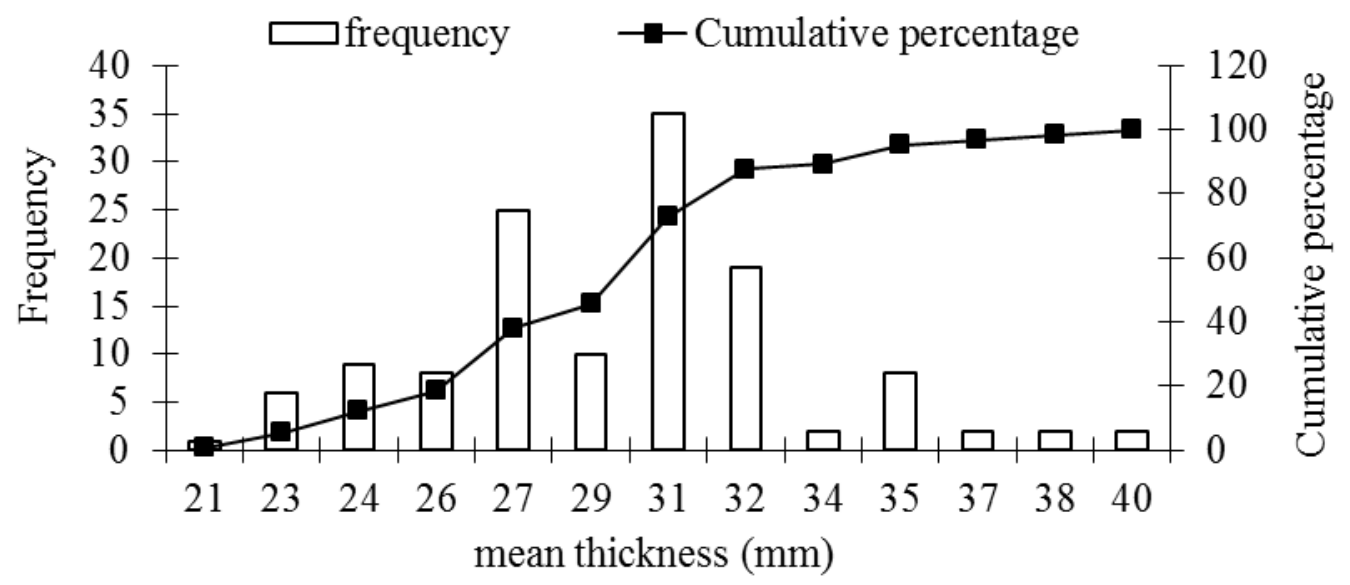

Figure 3. Mean thickness (mm) cumulative percentage frequency histograms for baru nuts (SP).

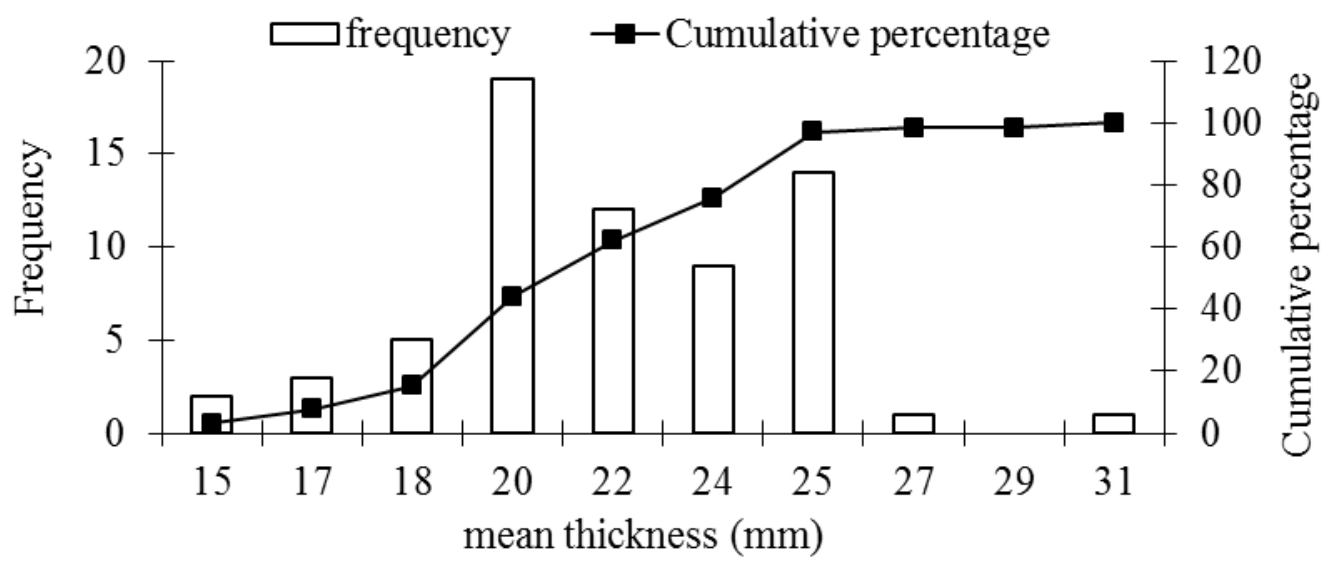

The resulting force-deformation curves, tests of $\mathrm{CP}$ and SP specimens, hydrated at $90^{\circ} \mathrm{C}$ regardless of conditioning, are illustrated by a for 30 minutes and pulped $(\mathrm{H})$, and pulped and typical curve in Figure 4. The biological yield point was not observed, and the increase of force to maximum force is monotonic. The rupture of the endocarp occurs with an abrupt decrease in force value, showing characteristics of a brittle material. Deformation imposed to maximum force was accompanied by the cracking and opening of the endocarp to release the kernel.

Average values and corresponding coefficients of variation for maximum force, deformation at maximum force $(\delta)$, specific deformation $(\varepsilon)$, and deformation energy (E), obtained in compression dried specimens at $150^{\circ} \mathrm{C}$ for 50 minutes (S), with moisture content on a dry basis of 8.68, 8.39, 21.23, and $0.49 \%$, respectively, are shown in Table 2 .

Average values of maximum baru endocarp rupture force, ranging between 7926.7 and 9284.4 N, were higher than that of cashew nuts (OGUNSINA; BAMGBOYE, 2013), which ranged between 318 and $784 \mathrm{~N}$ for natural nuts, 242 and 517 $\mathrm{N}$ for roasted nuts, and 309 and $436 \mathrm{~N}$ for cooked nuts. For hazel nuts (ERCISLI et al., 2011), these values ranged between 177.83 and $477.95 \mathrm{~N}$; for pistachio nuts (FADAVI et al., 2013), they ranged 
between 222, 15 and $370.46 \mathrm{~N}$; and for Persian nuts (GHARIBZAHEDI et al., 2012a) between 380.86 and 408.60, 60 N. However, all those values were lower than those obtained for babassu endocarp rupture, between 19.42 and $33.64 \mathrm{kN}$ (SOLER et al., 2007). Average values of maximum force at rupture of the specimen for the various treatments, although higher for hydrated fruit $(\mathrm{H})$, showed the same order of magnitude, ranging between 7927 and $9284 \mathrm{~N}$. This behavior contradicts the results obtained by Fadavi et al. (2013) for pistachios, and Gharibzahedi et al. (2012b) for different cultivars of nuts, where the rupture force decreased with moisture content increase.

Figure 4. Baru characteristic compression force-deformation curve.

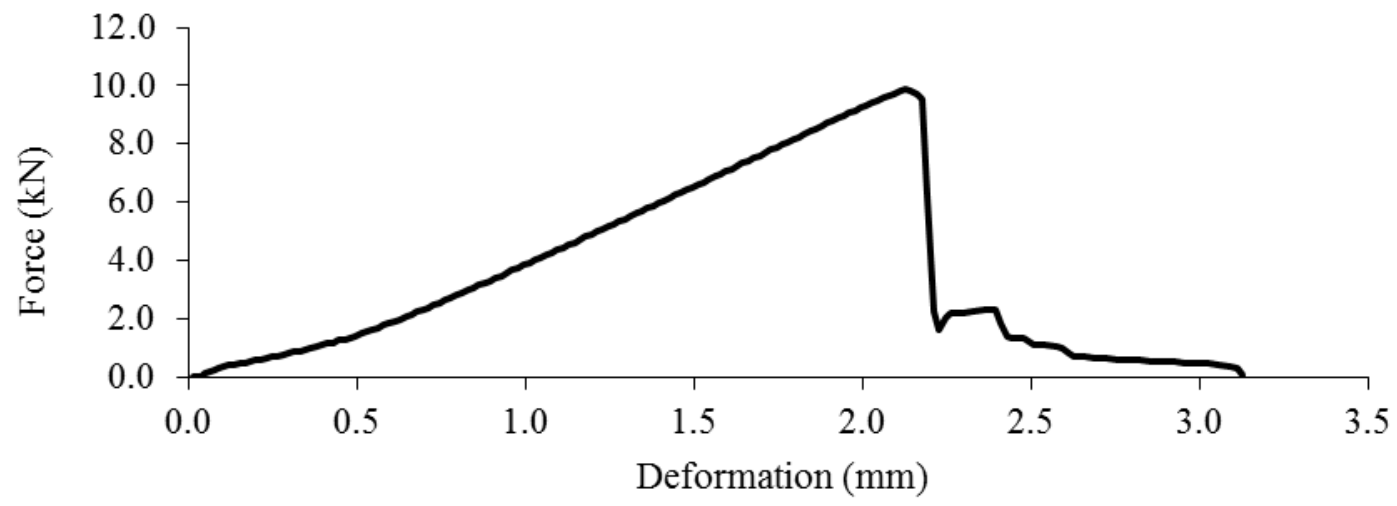

Table 2. Maximum force, deformation at maximum force $(\delta)$, specific deformation $(\varepsilon)$, and deformation energy $(\mathrm{E})$ mean values from compression tests of $\mathrm{CP}$ and SP specimens, hydrated at $90^{\circ} \mathrm{C}$ for 30 minutes, then pulped $(\mathrm{H})$, and pulped specimens dried at $150{ }^{\circ} \mathrm{C}(\mathrm{S})$.

\begin{tabular}{|c|c|c|c|c|c|c|c|c|c|c|c|c|}
\hline Treatment & Maxim & For & $(\mathbf{N})$ & & & & & im.mI & $\left.m^{-1}\right)$ & & E (J & \\
\hline $\mathrm{CP}$ & 8357.3 & (7) & $\mathrm{a}$ & 1.955 & (9) & b & 0.055 & (13) & & 7.00 & (12) & $\mathrm{a}$ \\
\hline SP & 8269.7 & (15) & $\mathrm{a}$ & 2.143 & (17) & $\mathrm{b}$ & 0.066 & (12) & b & 8.47 & (29) & $\mathrm{b}$ \\
\hline $\mathrm{H}$ & 9284.4 & (11) & b & 2.164 & (17) & b & 0.066 & (19) & b & 9.26 & (21) & $\mathrm{b}$ \\
\hline S & 7926.7 & (20) & $\mathrm{a}$ & 1.719 & (21) & $\mathrm{a}$ & 0.051 & (10) & $\mathrm{a}$ & 6.55 & (31) & a \\
\hline
\end{tabular}

Values in parentheses are coefficient of variation $(\%)$. All values with same letter in same column do not differ significantly $(\mathrm{p} \leq$ $0.05)$.

Coefficient of variation (\%), values appears between parentheses. Values corresponding to same letter in column do not differ (p $\leq 0.05)$.

Average deformation at maximum force $(\delta)$ presented a variation of between 1.719 and 2.164 $\mathrm{mm}$ for the considered treatments, corresponding to specific deformation ( $(\varepsilon)$ between 5.1 and $6.6 \%$ of the fruit width. Within this deformation range, $100 \%$ of whole kernels were released. Relatively low coefficient of variation values indicate that deformation and/or specific deformation has the potential to be used as the technological parameter of rupture, which is important for shelling mechanism design, since it sets a specific limiting deformation for obtaining whole kernels. Average deformation energy up to the maximum force (E) ranged between 6.55 and $9.26 \mathrm{~J}$. This parameter is important for the development of equipment that uses the same principle of compression between two plane plates. These results were obtained at a strain rate of 1 $\mathrm{mm} / \mathrm{s}$; that is, at a low strain rate. However, higher values of strain rate for enhancing viscoelastic effect, thereby reducing specific deformation at 
rupture, are considered in further studies, such as those used by Ogunsina and Bamgboye (2013) for cashew nuts.

Figure 5 shows images obtained using X-ray computed tomography for A) natural baru specimens (CP); B) hydrated $\left(90^{\circ} \mathrm{C} / 30 \mathrm{~min}\right)$ without pulp (H); and $\mathrm{C})$ dried $\left(150^{\circ} \mathrm{C} / 50 \mathrm{~min}\right)$ without pulp (S). In the three planes ( $\mathrm{x}, \mathrm{y}$, and $\mathrm{z}$ ), fruit details to scale, such as fractions of pulp, endocarp and kernel, can be observed.
Darker areas, the null attenuation, correspond to empty spaces, in contrast to brighter areas, which make it possible to determine the internal dimensions and characteristics in a nondestructive way. The average values of the total gap, F, corresponding to the sum of F1 and F2 gaps, showed no difference between treatments $(\mathrm{p} \leq 0.05)$, ranging from 5.46 to $5.53 \mathrm{~mm}$, with an average of $5.49 \mathrm{~mm}$. The inspection of images corroborates the hypothesis of the existence of more-susceptible-to-rupture points, such as discontinuities within the material, pore variation sizes, microcracks, and portions of reduced thickness along the endocarp.

Figure 5. X-ray tomographic images of single baru: A) in natura (CP); B) hydrated $\left(90^{\circ} \mathrm{C} / 30 \mathrm{~min}\right)(\mathrm{H})$; C) dried $\left(150^{\circ} \mathrm{C} / 50 \mathrm{~min}\right)$ without pulp (S).

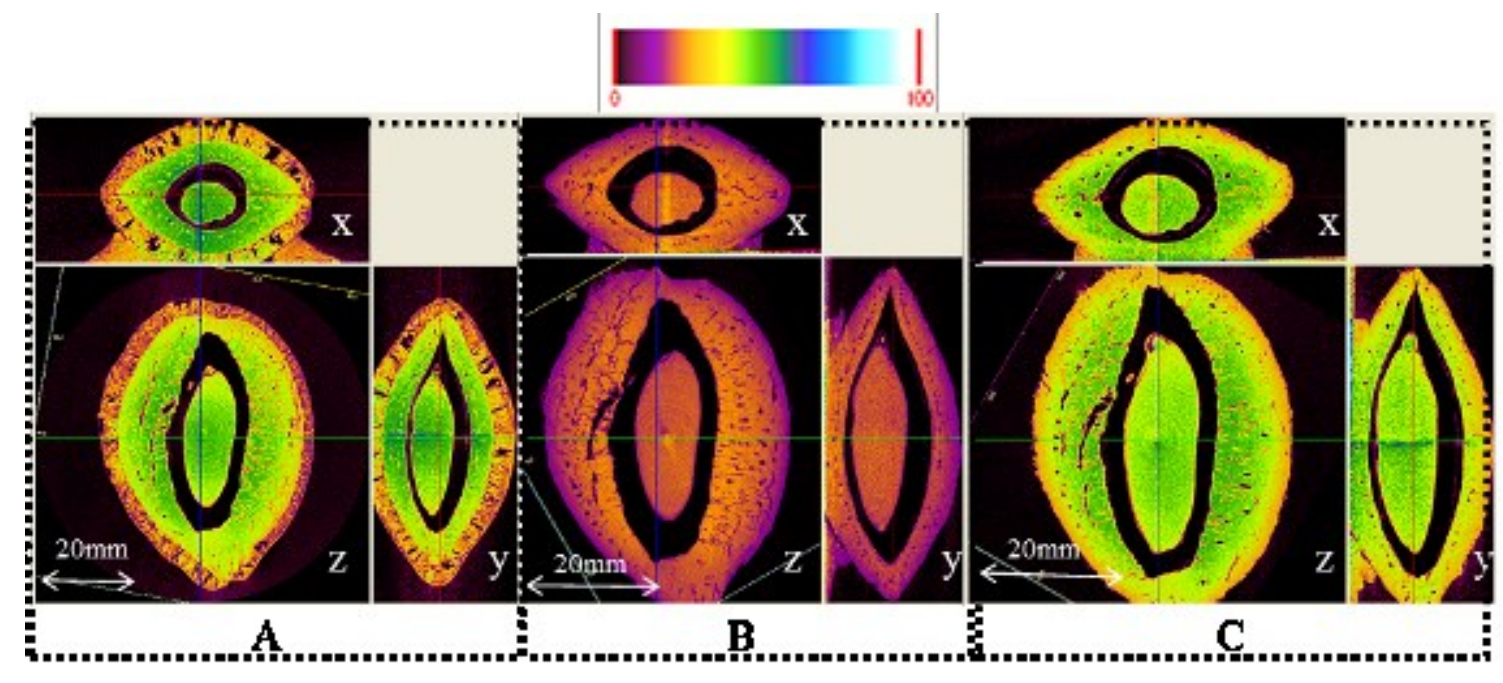

\section{Conclusions}

The determination of average values of unit mass, length, width, thickness, bulk, real density, endocarp rupture force, and corresponding specific deformations, as well as X-ray computed tomography, was performed for the physical and mechanical characterization of baru fruit and nuts.

It was concluded that length, width, and thickness of baru are distinct, with thickness being the most suitable parameter for classifying the whole fruit and nut.
Due to high endocarp resistance to rupture, the shelling mechanism design should consider such forces, which are markedly higher than several other nut species.

Independently of the type conditioning tested in this investigation, the widthwise compression of the endocarp was adequate to promote endocarp rupture, due to the stability of specimens during compression and the absence of mechanical damage to the kernel. 
$\mathrm{X}$-ray computed tomography-a nondestructive internal inspection procedure allowed visualization of the baru nut's endocarp irregularities, as well as points susceptible to rupture and internal gaps.

\section{References}

ALVARADO, J. D.; AGUILERA, J. M. Métodos para medir propriedades fisicas en industrias de alimentos. Zaragoza: Acribia, 2001. 410 p.

AMERICAN ASSOCIATION OF CEREAL CHEMISTS - AACC. Approved methods of american association of cereal chemists. St Paul: Minnesota, 2000.

ASSOCIATION OF OFFICIAL ANALYTICAL CHEMISTS - AOAC. Official methods of analysis. Gaithersburg: Maryland, 2011.

BASTOS, A. C.; FERRAZ, A. C. O. Mechanical properties of castor beans subject to different drying temperatures aiming to disrupt the bean coat. Engenharia Agrícola, Jaboticabal, v. 34, n. 1, p. 93-101, 2014.

CARRAZZA, L. R.; ÁVILA, J. C. C. Manual tecnológico de aproveitamento integral do fruto do Baru. Brasília: Instituto Sociedade, População e Natureza, ISPN, 2010. $56 \mathrm{p}$.

CORRÊA, G. C.; NAVES, R. V.; ROCHA, M. R.; ZICA, L. F. Caracterização física de frutos de baru (Dipteryx alata Vog.) em três populações nos cerrados do estado de goiás. Pesquisa Agropecuária Tropical, Goiânia, v. 30, n. 2, p. 5-11, 2000.

ERCISLI, S.; OZTURK, I.; KARA, M.; KALKAN, F.; SEKER, H.; DUYAR, O.; ERTURK, Y. Physical properties of hazelnuts. International Agrophysics, Lublin, v. 25, n. 2, p. 115-121, 2011.

FADAVI, A.; HASSAN-BEYGI, S. R.; KARIMI, F. Moisture dependent physical and mechanical properties of Syrjan region wild pistachio nut. Agricultural Engineering International, Beijing, v. 15, n. 2, p. 221230, 2013.
FERRAZ, A. C. O.; HONÓRIO, S. L. Propriedades físicas e mecânicas de frutas. In: NASCIMENTO, L. M.; DE NEGRI, J. D.; MATTOS JUNIOR, D. Tópicos em qualidade e pós-colheita de frutas. Cordeirópolis: Centro APTA Citros Sylvio Moreira, 2008. p. 141-154.

GHARIBZAHEDI, S. M. T.; MOUSAVI, S. M.; HAMEDI, M.; KHODAIYAN, F. Comparative analysis of new Persian walnut cultivars: nut/kernel geometrical, gravimetrical, frictional and mechanical attributes and kernel chemical composition. Scientia Horticulturae, Amsterdam, v. 135, p. 202-209, 2012a.

GHARIBZAHEDI, S. M. T.; MOUSAVI， S. M.; HAMEDI, M.; KHODAIYAN, F.; DADASHPOUR, A. Mechanical behavior of Persian walnut and its kernel under compression loading: an experimental and computational study. Journal of Food Processing and Preservation, Malden, v. 36, n. 5, p. 423-430, 2012 b.

INSTITUTO ADOLFO LUTZ - IAL. Normas Analíticas do Instituto Adolfo Lutz: métodos físicos e químicos para análises de alimentos. São Paulo: São Paulo, 2008. 1020 p.

NEVES, G. A. R. Influência do vapor sob pressão $e$ radiação infravermelha no desempenho da decorticação, qualidade do óleo e resistência mecânica da amêndoa de castanha do Brasil. 2012. Dissertação (Mestrado em Engenharia Agrícola) - Faculdade de Engenharia Agrícola, Universidade Estadual de Campinas, Campinas.

OGUNSINA, B. S.; BAMGBOYE, A. I. Fracture resistance of cashew nuts as influenced by pre-shelling treatment. International Journal of Food Properties, Philadelphia, v. 16, n. 7, p. 1452-1459, 2013.

SOLER, M. P.; VITALI, A. A.; MUTO, E. F. Tecnologia de quebra do coco babaçu (Orbignya speciosa). Ciência e Tecnologia de Alimentos, Campinas, v. 27, n. 4, p. 717$722,2007$. 
